\title{
Surgical and non-surgical intervention for speech rehabilitation in Parkinson disease
}

\author{
Heru Hendarto*, Steven Gray ${ }^{\dagger}$
}

\begin{abstract}
Parkinson disease is a common progressive neurological disorder with an unknown etiology. It has a high incidence of speech, voice and laryngeal abnormalities which vary due to the severity of the disease. In addition to tremor and supraglottic hyperfunction, bowed vocal folds may result as part of the aging process. This condition will cause an inadequate vocal fold adduction or hypoadduction. The approaches for speech rehabilitation in Parkinson disease are speech therapy or vocal fold augmentation. One of the most studied approaches is the Lee Silverman voice treatment for Parkinson disease. This program encourages maximum phonatory effort and improves voice quality. Vocal fold augmentation by injecting under direct visual control is one way to restore the focal fold function. The ultimate goal in the restoration of glottic insufficiency is to mimic nature as closely as possible. Although many clinical studies show promising results for the use of collagen injection for bowed vocal fold treatment, no study had shown the efficacy of injected vocal fold compared to voice treatment or the efficacy of combining both procedures.
\end{abstract}

\begin{abstract}
Abstrak
Penyakit Parkinson merupakan kelainan saraf yang progresif dan tidak diketahui penyebabnya. Kelainan ini mempunyai variasi kelainan wicara, suara, dan laring sangat tinggi yang sesuai beratnya penyakit. Keadaan ini sering dapat mempengaruhi produksi suara. Di samping tremor dan hiperfungsi supra-glotik, melengkungnya lipatan pita suara dapat terjadi karena proses penuaan. Hal ini yang menyebabkan tidak sempurnanya adduksi atau hiperadduksi. Rehabilitasi suara pada penyakit Parkinson adalah terapi wicara atau augmentasi plika vokalis. Salah satu penelitian yang banyak dilakukan adalah terapi wicara cara Lee Silverman yang memfokuskan kepada fonasi pada pengobatan kelainan suara pada penyakit Parkinson. Program ini mendapatkan hasil maksimal dan memperbaiki kualitas suara. Suntikan untuk menghasilkan augmentasi pita suara adalah salah satu cara untuk memperbaiki fungsi pita suara. Tujuan utamanya adalah memperbaiki insufisiensi glotik dengan mendekati glotik ke fungsi pita suara senormal mungkin. Walaupun banyak penelitian penyuntikan kolagen memberikan hasil yang menggembirakan, belum ada suatu penyelidikan yang membandingkan hasil suntikan pita suara tersebut dengan terapi suara atau kombinasi kedua cara.
\end{abstract}

Keywords: Parkinson disease, Lee Silverman, collagen injection, hypophonia

Parkinson (also known as paralysis agitans), is a common progressive neurological disorder that results from degeneration of nerve cells (neurons) in a region of the brain that controls movement. It has an unknown etiology due to deficiency of dopamine (important chemical transmitter in certain brain cells governing movement, balance and walking). Parkinson disease is a growing national problem, with over a million victims in the United States alone. There are 20 new cases of Parkinson's per 100,000 people per year. Most victims are over 40 years old although the disease can appear in younger patients. 1,2

\footnotetext{
"Department of Communication Disorders, University of Utah at Salt Lake City, Salt Lake City, Utah

'Department of Otolaryngology, Primary Children Medical Center, University of Utah School of Medicine
}

This condition was first described by James Parkinson in 1817 , although its symptoms and potential therapies were mentioned in the Ayurveda, the system of medicine practiced in India as early as $5000 \mathrm{BC}$, and in the first Chinese medical text, Nei Jing, which appeared 2500 years ago. ${ }^{2}$

The etiology is still unknown or idiopathic, but some researchers have mentioned the possibility of post head trauma, post-encephalitis or prolonged use of certain drugs. There are degenerative changes in the extra-pyramidal system especially at the substansia nigra and a few cells in the striatum. ${ }^{2-4}$ This will cause a dopamine deficiency, and is considered responsible for the primary disease symptoms. ${ }^{3,4}$

Patients are most often aware of tremor, slowness of movement, and gait impairment. In most patients with 
early stage, the disease is predominantly unilateral, so that the degree of functional impairment often depends on which hand is affected. Diagnosis is based on a neurological examination which covers evaluation of the symptoms and their severity. If symptoms are serious enough, a trial test of antiParkinson drugs may be indicated. Also when indicated, brain scans may be made to rule out other diseases with similar symptoms. ${ }^{1,3,4}$

The earliest symptoms of Parkinson disease may be nonspecific and include weakness, tiredness, and fatigue. Other characteristic symptoms for diagnosing purposes can be divided into primary symptoms: rigidity (increased tone in the muscles), tremor (smooth shaking of the limb or other part of the body), difficulty with balance, and difficulty in walking (due to rigidity, tremor \& balance incoordination). Secondary symptoms which may be presents include: depression, sleep disturbances, dementia (senility), speech problems the voice may sound (breathy, tremulous, high-pitched, hoarse, or strident), blepharospasm (is the inability to open the eyelids-or once opened), bradykinesia (slowness and proverty of movement), difficulty in swallowing (dysphagia), drooling (sialorrhea), constipation, breathing problems, difficulty voiding, dizziness, stooped posture, swelling of the feet, and sexual problems. ${ }^{3,4}$

There is no cure for Parkinson disease but some medication such as lepo dova (L-Dopa) can be given to minimize the symptoms. L-Dopa helps replenish some of the lost dopamine and when combined with other drugs, helps to stimulate the dopamine system or mimic its controlling effect on other nerve cells, such as bromocriptine, pergolide, selegilene and trihexyphemidye. ${ }^{1,2,4}$
Operative procedures such as transplantation of tissue into the area of the basal ganglia that accepts dopamine from the brain-stem is another treatment possibility. This area is called the striatum and is divided into the caudate nucleus and the putamen. Dopamine-producing tissue has been transplanted into areas of the striatum with increasing success. In 1950, an ablative surgical procedure was first performed. Most therapies including tissue trans-plantation are aimed at increasing the production and/or transmission of dopamine. This new procedure is done by placing a small leison (hole) in the circuit. The circuit can be interrupted safely in human in the globus pallidus (pallidotomy) or the thalamus (thalamotomy). Thalamotomy can alleviate tremor in the body opposite to the side of the brain that is operated upon with up to $98 \%$ effectiveness. Problems associated with thalamotomy include loss of muscle tone, balance impairment, and speech impairment. These occur with greater frequency in patients getting bilateral (both sides of the brain) surgery. Pallidotomy helps bradykinesia (slowness of movement) more than tremor. Balance and speech are usually improved even after only one surgery (unilateral pallidotomy). Both thalamotomy and pallidotomy reduce the involuntary movements that occur (dyskinesias) as a side effect of anti-Parkinson disease medicines. ${ }^{5}$

\section{PHYSICAL FINDINGS}

One of the characteristics of Parkinson disease from the laryngeal examination in addition to tremor and supra glottic hyperfunction, are bowed vocal folds (see figure 1). ${ }^{6,11}$ Bowed vocal folds are literally folds that look like two bows joined at the front and back. ${ }^{11}$ The result is a lack of closure in the middle

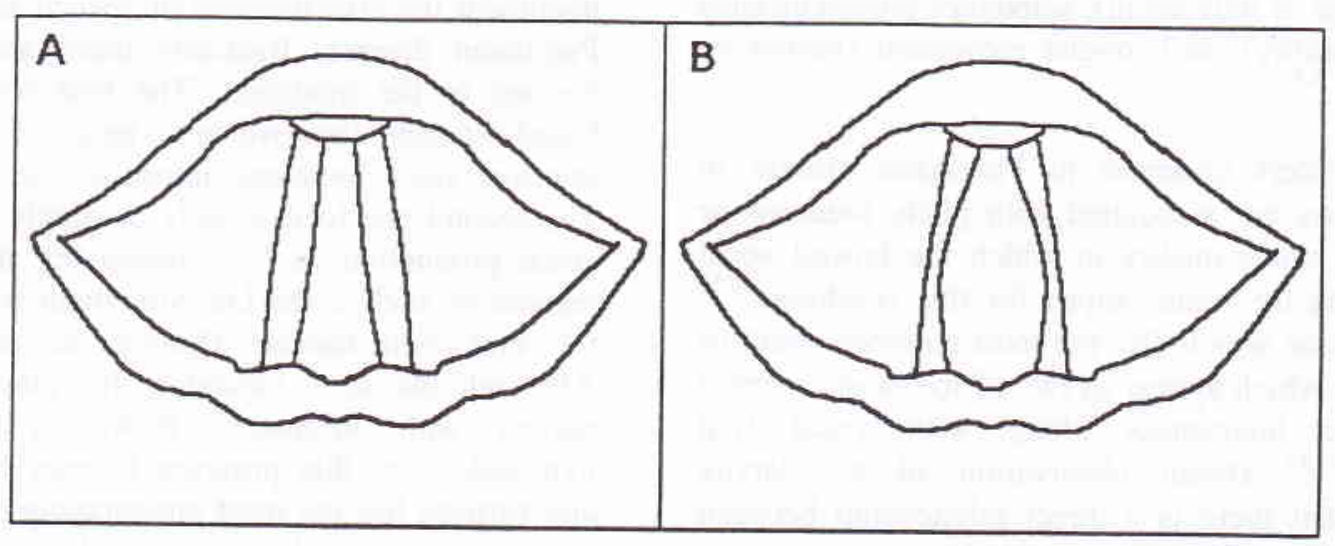


part of the vocal folds, and over time, may results in a loss of muscle bulk in the vocal folds that causes more difficulty for vocal fold closure. ${ }^{8,9}$ Bowing at any age comes from a subtle lack of "nerve" input to the vocal folds. Typical symptoms are weak voice and vocal fatigue. ${ }^{8,11,12}$

This condition which is the most common result of senescence, can be diagnosed by using a videostroboscopy method. ${ }^{13,14}$ Laryngolosits suspect empirically that this condition is due to the atrophy of the thyroarytenoid muscles. They also indicated that there is contribution of cricothyroid muscle atrophy. ${ }^{8,11}$ Physiological changes in bowed vocal fold may developed from muscular weakness due to lack of nerve innervation, paralysis, thinning of the connective tissue and disorganization of the myofibril. This may be further compounded by a decrease in the tissue of the superficial and intermediate layer of the lamina propria. ${ }^{8,11,13}$ This condition also can be related to the extent of removal of the vocal fold tissue in laser surgery. Bowing of the vocal fold as part of the aging process appears as one of the two most common causes for hoarseness, along with vocal fold paralysis. ${ }^{7,10,11,12}$ Because of this condition, the vocal fold may adduct posteriorly but not medially which will cause and inadequate vocal fold adduction or hypoadduction. ${ }^{10,12}$

\section{CHANGES IN VOICE PRODUCTION}

There is a high incidence of speech, voice and laryngeal abnormality which varies due to the level of the disease itself. The individuals may have problems with phonation (hoarseness, roughness, breathiness, and tremulousness due to laryngeal dysfunction), articulation (articulatory undershoot, rigidity and reduce range of movement), resonance (co-occurrence of hypernasality), and tongue movement (tremor of the tongue). ${ }^{6,7}$

Voice disorders common in Parkinson disease in which many are associated with pitch, loudness or changes in voice quality in which the bowed vocal fold may be the main culprit for this condition. ${ }^{10,15}$ This condition which also the most common result of senescence which appear as two of the most common causes for hoarseness along with vocal fold paralysis. $^{7,11,12}$ Direct observation of the larynx indicated that there is a direct relationship between breathiness ad reduced loudness with the gap created by the bowed vocal folds. ${ }^{7,8,11}$
Vocal production of patient with Parkinson disease are characterized by low vocal intensity, monotone and hoarseness. ${ }^{715}$ This condition may contribute to a reduction in speech intelligibility, ${ }^{16,17}$ and reduced vocal folds adduction due to bowed vocal fold., ${ }^{72}$ The perceptual features of hypokinetic dysarthria (including reduced in ability to sustain phonation and loudness) indicate for an impaired respiratory function (See Table 1). ${ }^{15,18}$

Table 1. Speech characteristics of Parkinson disease

\begin{tabular}{lll}
\hline & Pathophysiology & Speech characteristics \\
\hline Respiration & $\begin{array}{l}\text { Muscular rigidity, } \\
\text { tremor of the } \\
\text { respiration muscle } \\
\text { and weak } \\
\text { inspiration }\end{array}$ & $\begin{array}{l}\text { Low intensity, mono } \\
\text { pitch, vocal tremor } \\
\text { and hypokinetic } \\
\text { dysarthria }\end{array}$ \\
Phonation & $\begin{array}{l}\text { Incomplete } \\
\text { closure of the } \\
\text { vocal folds, } \\
\text { bowing, tremor of } \\
\text { the vocal folds } \\
\text { and supra glottic } \\
\text { hyperfunction }\end{array}$ & $\begin{array}{l}\text { Breathy, hoarse, } \\
\text { roughness, tremulous } \\
\text { voice, reduced } \\
\text { phonation range }\end{array}$ \\
Resonance & $\begin{array}{l}\text { Velopharyngeal } \\
\text { incompetence due } \\
\text { to rigidity } \\
\text { Tremor, rigidity } \\
\text { and reduce range } \\
\text { of movement of } \\
\text { the articulator }\end{array}$ & $\begin{array}{l}\text { Articulatory } \\
\text { undershoot, imprecise } \\
\text { articulation and } \\
\text { reduce speech } \\
\text { intelligibility }\end{array}$ \\
\hline
\end{tabular}

\section{SPEECH INTERVENTION FOR VOICE DISORDER IN PARKINSON DISEASE}

There is a long history of research attempting to document the effectiveness of speech intervention in Parkinson disease. Basically there are two major focuses of the treatment. The first one is a broad based speech improvement program designes to improve voice loudness, intonation and articulation. The second one focuses only on single aspect of the voice production such as improving the voice and respiration such as the Lee Silverman voice treatment for Parkinson disease (Ramig, et all, 1995). ${ }^{19,20}$ Although the ideal candidate for intervention is a patient with idiopathic Parkinson disease and hypoadduction, this program focuses on phonation, and perhaps has the most encouraging results for the treatment of speech disorder related to Parkinson disease because it encourages maximum phonatory 
effort in order to bring vocal folds together and improve voice quality. This program is driven by a number of perceptual features of phonation in Parkinson disease such as reduced in pitch and loudness, breathiness, and hoarseness. ${ }^{20,21}$

The main goal of the Lee Silverman Voice Treatment for Parkinson disease is to increase vocal fold adduction as well as respiratory volume. ${ }^{17,20}$ This is the most studied treatment and the one with the best results so far and is done by encouraging the patient to "Think Loud!" Increased phonatory effort is accomplished in a series of graded therapy tasks that focus on increasing loudness, increasing intonation, and reducing hoarse voice quality. Patient receives four treatment sessions per week for four weeks. Outcome measures included a comprehensive range of aerodynamic, acoustic, and perceptual measures. Sessions typically include both practice on simple phonatory tasks (such as sustaining phonation as long as possible) and practice in maintaining phonatory effort in speech activities, beginning with short phrases and progressing to longer utterances. The clinician role is to give patients objective feedback about their performance; for example, length of maximum phonation or fundamental frequency range. The clinician strongly encourages maximum performance throughout the session and provides home practice drills to elicit maximal levels of performance. ${ }^{20,21}$

Ramig et al, ${ }^{20}$ suggest that there are a number of keys to the success of this type of treatment:

1. Simplicity

The therapy is simple, focusing only on the phonatory aspects of speech production. Because people with Parkinson disease are known to have difficulty simultaneously executing two movements, simplifying the focus and instructions may increase the probability of successful learning.

2. Focus

Focus also on non-phonatory aspects of speech production. Speaking rates may be slowed, oral articulatory. gestures may be extended, and overall speech intelligibility may be improved. This may be related to an overall increase in physiologic effort.

3. Intensive treatment

The intensive treatment with immediate transfer of skills to speech is highly motivating. Speakers and their spouses report immediate improvements, thus encouraging them to work even harder to bring about more changes.
4. Calibration

Individuals with Parkinson disease appear to have difficulty gauging what is an appropriate level of phonatory effort. Patient testimonies suggest that their perceived level of effort must be "recalibrated to insure successful carryover". Speakers often report that they do not realize their voices are soft or weak prior to treatment. Early in treatment, many reported feeling as if they were shouting in order to produce "normal" voicing. With continuous feedback and other techniques such as review of audiotape recordings, speakers are taught to become comfortable with the new loudness level. Therefore, a focus on selfawareness and accurate calibration of the amount of effort needed to produce acceptable voice also appear to be critical treatment features.

\section{SURGICAL INTERVENTION FOR VOICE DISORDER IN PARKINSON DISEASE}

Recent advances in phonosurgery have resulted in several new approaches to the management of bowed vocal folds. The ultimate goal in the restoration of bowed vocal folds is to mimic nature as closely as possible. Focal fold augmentation by injection under direct visual control is possible to restore the focal fold augmentation by injection under direct visual control is possible to restore the focal fold function. ${ }^{22}$ Remacle et al (1990), Bless et al (1992), and Ford et al (1995) use vocal fold injections in their treatment of glottic insufficiency. These are a broad studies which include bowed vocal folds among the subjects and show a promising result for the injection of collagen in bowed vocal folds. ${ }^{20,23,24}$ The studies also suggest that in patients with relatively minimal glottic insufficiency who are bothered by weak, breathy voice production, collagen injection may be a relatively safe and successful method of treatment. Many patients with prebylaryngis, with bilateral paresis from neurologic disease or trauma, and with bowing due to cricothyroid muscle weakness fit in this group. ${ }^{23}$

In an article by Burke, et al (1999), collagen injection was used in their study of 35 Parkinson patient with hypophonia. This was a non controlled study of subjective satisfaction with the procedures as reported by each patient. This suggest that the augmentation may have a role in the management of hypophonia in Parkinson disease although further research is needed. ${ }^{3}$ 
One of the issue on injecting foreign materials is viscocity and elasticity of the vocal tissues is affected by the introduction of the foreign biomaterial because the phonation threshold pressure for vocal fold oscillation is directly related to the viscosity of the vocal fold mucosa. A material with a low viscosity flows easily, with little internal energy being dissipated in the shearing process. A highly viscous material flows more slowly and dissipates more energy in the process. At the microscopic level, this resistance depends on the ease of relative shear or slippage between molecules of the material, which is determined by different kinds of intramolecular and intermolecular interactions such as physical entanglement, electrostatic forces (e.g., hydrogen bond), hydrophilic and hydrophobic interactions, and chemical interactions. The stronger the molecular interactions, the more resistant the molecules are to slippage, and the higher the viscosity. ${ }^{22}$

Numerous materials have been used over the years for vocal fold augmentation. Synthetic polymer Teflon is much more viscous than the other (biologic) materials. Denatured or partially hydrolyzed collagen and gelatin have a higher dynamic viscosity than collagen. The chemically cross-linked collagen shows a higher dynamic viscosity than noncross-linked collagen, as expected from the formation of many covalent crosslinks in tropocollagen. Fat has a lower dynamic viscocity than collagen, probably because of its very different molecular composition. ${ }^{22}$

The collagen implant consists of bovine collagen modified by solubilization and cross-linking to reduce cellular and humoral host immune response, but it is histologically similar to the deep lamina propria tissues in the vocal fold. The procedure requires no external incisions on the neck. Most important, results appear to be long-lasting, which has been confirmed objectively and subjectively. ${ }^{22,23}$ Injected collagen closely resembles host tissues at the vocal fold lamina propria. Like other bioimplants, it promotes ingrowth of host tissues and eventual replacement of injectate with host collagen.

One of the unique properties of injected collagen is the apparent tissue softening that occurs when the collagen is placed in scar tissue. The events following collagen injection that affect vocal fold function specifically include the gradual variable resorption of injected collagen, the replacement of some resorbed implant by deposition of new host collagen from metabolically active invading host fibroblasts, and the softening of existing scar tissue, probably due to fibroblastic production of collagenase. ${ }^{24,25}$ Small amounts $\left(0.05\right.$ to $\left.0.20 \mathrm{~cm}^{3}\right)$ of collagen injected in the plane of the vocal ligament and the intermediate layer of the lamina propria were successful at producing improved voices. ${ }^{23}$

Although bovine collagen is widely available, autologous collagen will most likely have even greater persistence than bovine collagen; because autologus collagen molecules are preserved in the preparation process. ${ }^{23,24}$

According to Remacle et $\mathrm{al}^{23}$ collagen does have some disadvantages. 1) Its is not cross-linked, and its sensitivity to fibroblast-secreted collagenase could lead to long-term resorption. 2) The microfibrils consolidate in situ after the injection. 3) Water - a volume equivalent of at least $60 \%$ of the injected volume of collagen - is eliminated, requiring overinjection. Three percent to $4 \%$ of patients injected with collagen are hypersensitive to it.

Resorption is reduced when collagen is injected into more superficial vocal fold levels (superficial lamina propria) and, in many patients, a superficially injected implant could be seen easily through the transparent mucosa years after injection. Most of the patients receives immediate relief after injection, and if the implants is properly placed in the lamina propria, gradual resorption and replacement allow the vocal mechanism to compensate incrementally for small changes. ${ }^{23}$

\section{CONCLUSIONS}

Parkinson disease is a common neurological disease which affects a large number of elderly adults, and occasionally develops in young adults as well. The disease is caused by dopamine deficiency which effect many movements including walking and handwriting that become very small and weak over time. For most patients, voice and speech become weak and slurred as well.

One of the characteristics of Parkinson disease from the laryngeal examination, in addition to tremor and supra glottic hyperfunction is bowed vocal fold which results in opening of the middle part of the vocal folds. The most common cause of bowing is presbylarynx (old larynx) due to subtle lack of "nerve" input to the vocal folds. However, there is an 
indication that bowing might be the result of senescence.

Voice disorders are common in Parkinson disease. They are associated with pitch, loudness or changes in voice quality. The voice is characterized by low vocal intensity, monotone and hoarseness which may contribute to a reduction in speech intelligibility, reduced in ability to sustain phonation and loudness due to an impaired respiratory function.

The most effective treatments for speech and voice problems associated with Parkinson disease appear to be intensive ones that involve daily therapy or nearly daily therapy for a few weeks. The most studied treatment and the one with the best results so far is called Lee Silverman Voice Treatment which focus only on single aspect of the voice production such as improving the voice and respiration. This method has the most encouraging results for the treatment of speech disorders related to Parkinson disease because it encourages maximum phonatory effort in oder to bring vocal fold together and improve voice quality.

Recent advances in phonosurgery have resulted in several new approaches to the management of glottic insufficiency. The ultimate goal in the restoration of glottic insufficiency is to mimic nature as closely as possible. Vocal fold augmentation by injecting collagen under direct visual control is one way to restore the vocal fold function. Injected collagen is an active bioimplant that closely resembles host tissues at the vocal fold lamina propria. Although many clinical studies show promising results for the use of collagen injection for bowed vocal fold treatment, no study had shown the efficacy of injected vocal fold compared to voice treatment or combining both procedures.

Finally, it is apparently useful to study the efficacy of voice treatment with collagen injection or the efficacy of combining both procedures especially for the treatment of voice disorders for patients with Parkinson disease. Future research should focus on examining short and long term effects of both treatments.

\section{REFERENCES}

1. Yorkston KM, Miller RM, Strand EA. Management of speech and swallowing in degenerative diseases. Tucson, AZ: Communication skill builder, 1995.
2. Nusbaum RL, Biesecker LG, Pavan WJ, Schwartzberg PL, Suchy S, Boris AW. Background information on Parkinson disease. In National Institute of Health Division of Intramural Research Report [On - Iine], 1998. Available: http://www/nhgri.nih.gov/DIR/LGDR/PARK/about_parks html.

3. Berke GS, Gerratt B, Kreiman J, Jackson K. Treatment of Parkinson hypophonia with percutaneous collagen augmentation. Ann Otol Rhinol Laryngol 1999; 108: 22731 .

4. Larsen HR. Parkinson disease: Is Victory in sight? International Journal of Alternative and complementary Medicine, 1997; 15: 22-4.

5. Cosgrove GR. Surgery for Parkinson disease. In Functional and stereotactic neurosurgery, Harvard Medical School [On-line], 1998. Available: http://neurosurgery.mgh.harvard.edu/fnctnlhp.htm\#PDSur gMGH.

6. Netsel R. A neurobiologic view of speech production and the dysarthria's. San Diego, CA: College Hill Press, 1986.

7. Perez KS, Ramig LO, Smith ME, Dromey C. The Parkinson larynx: termor and videostroboscopic findings. Journal of Voice 1996; 10: 354-61.

8. Smith ME, Ramig LO. Neurological disorders and the voice. In Rubin JS, Staloff RT, Korovin GS, Gould WJ, Eds. Diagnosis and treatment of voice disorder. New York, NY: Igaku - Shoin, 1995: 203-24.

9. Ramig LO, Scherer RC. Speech therapy for neurologic disorder and the larynx. In Blitzer A, Brin MF, Sasaki CT, Fahn S, Harris KS (Eds.), Neurologic disorder of the larynx. New York, NY: Thieme Medical Publisher, Inc, 1992: 163-82.

10. Lundy DS, Silva C, Casiano RR, Xue JW. Cause if hoarseness in elderly patients. Otolaryngol - Head Neck Surg, 1998; $118: 481-85$.

11. Tanaka S, Hirano M, Chijiwa K. Some aspect of vocal folds bowing. Ann Otol Rhinol Laryngol 1994; 103:35762.

12. Smith ME, Ramig LO, Dromey C, Perez KS, Samandari. Intensive voice treatment in Parkinson disease: Laryngostroboscopic findings. Joumal of Voice 1995; 9: 453-9.

13. Hirano M, Kurita S, Sakaguchi S. Aging of the vibratory tissue of human vocal folds. Acta Otolaryngol (Stokh), 1989; 107: 428-33.

14. Woo P, Casper J, Colton R, Brewer D. Dysphonia in the aging: Physiology versus disease. Laryngoscope 1992; 102: 139-44.

15. Critchley EMR. Speech disorders of Parkinsonism. A review joumal of neurology. Neurosurgery and Psychiatry 1981; 44: 751-58.

16. Ramig L, Bonitati C, Lemke J, Horri Y. Voice treatment for patients with Parkinson disease: Development of an approach and preliminary efficacy data. Journal of Medical Speech-Language Pathology 1994; 2: 191-209.

17. Dromey C, Ramig LO, Johnson AB. Phonatory and articulatory changes associated with increased vocal intensity in Parkinson disease: a case study. Journal of Speech and Hearing Research 1995; 38: 751-64.

18. Ramig LO, Dromey C. Aerodynamic mechanisms underlying treatment related changes in vocal intensity in 
patients with Parkinson disease. Journal of Speech and Hearing Research 1996; 39: 798-807.

19. Ramig L, Countryman S, Thomson L, Horri Y. Comparison of two forms of intensive Speech. treatment for Parkinson disease. Journal of Speech and Hearing Research 1995; 39: 1232-51.

20. Ford CN, Bless DM, Loftus JM. Role of injectable collagen in the treatment of glotic insufficiency: A Study of 119 Patients. Ann Otol Rhinol Laryngol 1992; 101: 237-47.

21. Ramig L, Countryman S, O'Brien C, Hoehn M, Thomson L. Intensive speech treatment for patients with Parkinson disease: Short-and long-term comparison of two techniques. Neurology 1996; 47: 1496-1504.
22. Chan RW, Titze IR. Viscosities of Implantable Biomaterials in Vocal Fold Augmentation Surgery. Laryngoscope 1998; 108: 725-31.

23. Remacle M, Marbaix E, Bertrand B, Hamoir M, Eeckhaut JVD. Corection of glottic insufficiency by collagen injection. Ann Otol Rhinol Laryngol 1990; 99: 438-44.

24. Ford CN, Staskowski PA, Bless DM. Autologous collagen vocal fold injection A preliminary clinical study. Laryngoscope 1995; 105: 944-48.

25. Ford CN, Bless DM. A Preliminary study of injectable collagen in human vocal fold augmentation. Otolaryngol Head Neck Surg 1986; 1: 104-112. 